\title{
FARMER INNOVATIVENESS AND ITS IMPACT ON INTERNET AND SOCIAL MEDIA ADOPTION ${ }^{1}$
}

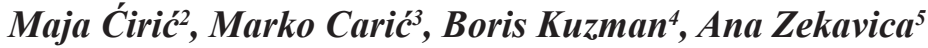

\begin{abstract}
Summary
In recent years, huge efforts have been made to implement ICT innovations in the agricultural sector in order to increase its competitiveness. The question that can be posed is what depends on the successful implementation of ICT innovations among farmers. Numerous scientific papers were published with the purpose of identifying factors that affect acceptance of particular innovation by users. The aim of this paper was to determine whether the farmer innovativeness influences the acceptance and the degree of using the Internet and social media by farmer. Additionally, statistically significant correlation between the demographic factors of the farmers and their innovativeness was investigated. The research was conducted using survey method. Descriptive statistics, Correlation analysis using Pearson's correlation coefficients and Chi-square test were used as statistical methods. Obtained results confirmed the initial hypotheses and based on that recommendations for the creation of a marketing strategy for introducing new ICT solutions in the field of agriculture are made.
\end{abstract}

Key words: farmer innovativeness, Internet, social media, marketing research, demographic characteristics, precise agriculture

JEL: $M 31, Q 13$

\section{Introduction}

The use of the Internet and social media in agriculture becomes inevitable for improving the competitiveness of this sector. There are numerous benefits that can be achieved

1 Paper is part of project III 46006 - Sustainable agriculture and rural development in function of achieving strategic goals of Republic of Serbia within Danube region, funded by Ministry of Education, Science and Technical Development of Republic of Serbia

2 Maja Ćirić, Ph.D., Associate Professor, Faculty of Economics and Engineering Management in Novi Sad, 021 / 400-484 majaciric79@yahoo.com,

3 Marko Carić, Ph.D., Full Professor, Faculty of Law, Economics and Justice, Novi Sad, marko@pravni-fakultet.info

4 Boris Kuzman, Ph.D., Associate Professor, Institute of Agricultural Economics, Belgrade, kuzmanboris@yahoo.com

5 Ana Zekavica, MA., Teaching Assistant, Belgrade Business School, ana.zekavica@gmail.com

EP 2018 (65) 1 (243-256) 
by using the Internet and social media: better information flow, better promotion and easier access to customers, possibility of creating virtual markets, interconnecting small farmers and applying precise agriculture. However, Internet and social media are a discontinuous innovation, which implies a new way of using an unknown product until then. Therefore, their acceptance depends on the resistance that consumers have towards innovations. As innovations fit more into the existing system of beliefs and habits of consumers, it will be more quickly accepted.

The process of innovation acceptance is influenced by many factors: product characteristics, i.e. innovation characteristics, compatibility - the degree to which innovation fits into the existing system of values and individual experiences, complexity - the degree of which it is relatively difficult to understand or use, the divisibility the degree to which innovation can be tried on a limited basis, communicativeness - the degree to which the results of its use can be observed, the reference group and individuals, the socio economic system and the mass media of mass communication (Kotler, P., 1988, pp.356-357).

Rogers E. M. (1962, p.162) states that people differ from each other reflecting their willingness to accept innovation. Based on the time of acceptance of innovation, consumers are divided into innovators, early adopters, early majority, late majority and laggards.

Identifying these consumer groups is important in order to create an appropriate marketing strategy for the successful introducing of innovation on the market. However, it is difficult to identify some key trait for these groups of consumers because they differ for different products (Novaković, Rajačić, B. 2005).

Therefore, the aim of this paper was, first of all, to determine whether the farmer innovativeness will affect acceptance and intensity of using the Internet and social media. In addition, it is important to determine whether farmers who are grouped by tendency to use innovative products and technologies differ from each other in demographic characteristics.

Answers to these questions will facilitate to identifying the demographic profile of farmers that belongs to the group of innovators and early adopters and enable all the companies that try to implement various ICT innovations in agriculture to focus on them.

\section{Consumer innovativeness and its measurement}

Many studies on innovation focus on organizational innovations, new product characteristics, and consumers' response toward such innovations. According to Pauwels et al. (2004), innovation is actually treated as a key driver for the success of business organizations. Although there are constant and new innovations in the design of products (technological innovations), marketing and supply chain (non-technological innovation), service delivery (process innovation), and so on, Srinivasan et al. (2009) described most of the new products as failures at the introductory stage of their life cycle. The main reason behind this huge failure of new product innovations is the 
inability of marketers to understand consumer needs and wants. In other words, their inability to conceptualize consumer innovativeness might be a strong reason (Kaushik, A.K., Rahman, Z., 2014). Bearing in mind we considering farmers as consumers of the Internet and the social media, it is necessary to analyze their innovativeness as consumers, i.e. their consumer innovation.

Kaushik, A.K. and Rahman, Z., (2014, p. 244) found three basic dimensions of consumer innovativeness (CI), i.e., innate innovativeness (II), domain-specific innovativeness (DSI), and innovative behavior (IB). The first perspective of consumer innovativeness is a generalist perspective, which identifies consumer innovativeness based on their innate innovativeness. This perspective treats consumer innovativeness as a personality trait or characteristic of any individuals that differentiates them from others in their society (Hilgard, Atkinson, and Atkinson 1975). Innovativeness was traditionally assumed to remain constant over a person's lifetime because it was treated as an individual personality trait. However, this general approach was not entirely adequate because consumer innovativeness may be more related to the consumer interest in a certain product category than with its own characteristics (Citrin et al., 2000).

Bearing in mind that certain research showed that consumer innovation does not have to be constant throughout the life of consumers and under the influence of social factors, another key perspective of consumer innovativeness appeared, called the particularist perspective.

This perspective of consumer innovativeness treated innovativeness in a specific domain of a consumer's interest and renamed innovativeness as domain-specific innovativeness. The third and final perspective of consumer innovativeness is the integrator perspective, which proposes an intermediary level of the first two perspectives, i.e., the generalist and particularist perspectives of the consumer innovativeness. It supports both the perspectives and considers consumer innovativeness to be a constant and global in nature, but only to some extent and not exactly in all domains of consumers' interest. According to this perspective, individuals might show a uniform attitude toward adopting an innovation in a specific or few domains, but not for all the domains of their interest. It actually depends upon the situation and need of that particular change for the consumer at the same time (Kaushik, A.K. and Rahman, Z., 2014, p.247).

Researchers have developed a variety of measures for consumer innovativeness (Roehrich 2004). One of the most extensive research carried out on the consumers in the 15 major world economies took into the account ten items reflecting various constructs of innovativeness and on the basis of factor analysis identified three dimensions: openness, enthusiasm, and reluctance (Tellis, GJ, Yin, E., Bell, S., 2009, p.15).

The first two dimensions are primarily positively valenced, while the third one is negatively valenced. Their analysis shows that the positively valenced items suffer from social desirability bias, while the negatively valenced scale, reluctance, does not. Based on the results of this research, we created three questions in the questionnaire we used for measuring innovation of farmers in Vojvodina. 
Researchers have long suspected that the innovative consumer can be described by various demographics. Identifying these demographics remains important to marketers because they help with targeting decisions. Given that researchers in different ways define consumer innovativeness, there is no single view of how demographic factors are related to consumer innovativeness.

Several studies showed the relationship between sex, age, education, income and mobility with consumer innovativeness, but some reported lack of relationship between consumer innovativeness and demographic factors (Tellis, GJ, Yin, E., Bell, S., 2009, p .6).

Bearing in mind the opposite results presented in scientific literature, it is important to determine whether there is a correlation between the most important demographic factors and the consumer innovativeness of farmers in Vojvodina.

\section{The importance of Internet and social media for farmers}

Agricultural development faces multiple challenges including 1) climate change, 2) sustainable natural resource management, 3) food security, 4) shortages of fresh water, 5) limited availability of agricultural land, and 6) changing consumer expectations. In this context, ICT can play an important role in improving efficiency and leading to smart farming in the future of agriculture (Guerrini, 2015). Today's modern farms are adopting new technologies and generating unprecedented amounts of data, including field-specific information, yield mapping, soil moisture and nutrition, weather, leaf-area index, insects, and farm management data. Data collected from farms are a fundamental block for data-driven farming decision, and it is critical to turn the data into value to support better farming decision making. ICT now plays increasingly important role in future farming (Xin, J. Zazueta, F., 2016, p. 276).

In the research conducted on the sample of agricultural producers in Serbia, Montenegro and Bosnia and Herzegovina (Novalić, F., Selimović, F. and Biševac, F., 2011.) concluded that Internet is a rich source of informative and educational content. E-trade is represented in agriculture; at certain moment, some jobs, such as stock exchange trading and informing, can only be made via the Internet. Same research establish that small number of farmers uses the Internet and the benefits it provides.

In the research (Ćirić, M., Kuzman, B., 2017), a significant increase of Internet use by agricultural producers was revealed. According to the obtained results of these authors, the Internet is used by $66.47 \%$ of respondents on the daily level. This result is considered satisfactory, because it is on the level that is characteristic for countries in Europe but lower in the USA. However, although the percentage of farmers who use Internet is significantly increased compared to the previous period, the purpose of using Internet and especially Social networks is primarily entertainment, not business. In conclusion, the authors cite recommendations that would change the purpose of using the Internet in favor of improving their work. 
Social media has an amazing growth within few decades. It has become part of everyday life for most people in the developed and developing countries. At present social media is the world's largest communication network. It is the simplest and fastest way for sharing information such as file, photos, videos etc. Social media is not only a tool for reaching large audiences; it is also an opportunity to develop relationships (Jijina C.K, Raju G., 2016, p. 22). Social media can be defined as a type of website through which it is easy to connect the modern Internet technology (Web 2.0) with user interaction.

The biggest advantages of social media and the reason for the great popularity of certain services of this type are ease of use and real two-way communication. Consequently, the use of social media for achieving different goals is a great challenge in the whole world, also in Serbia. Currently, the most popular social media in Serbia, among different user groups are: Facebook, Twitter, Instagram, LinkedIN, YouTube (Ljubojević, Č. Ćirić, M., 2017).

Development and introduction of smart phones, broadband and $3 \mathrm{G}$ mobile networks have provided opportunities for farmers to connect with their peers in spite of the distance separating them. Farmers can use Internet tools such as web forums for discussion and debate, Internet searches, digital versions of farmer magazines (Farmers Weekly, 2016) to learn new knowledge, query problems, and access information on their phones, even in the middle of a field. Moreover, social media, such as Twitter, Facebook or a Google group, enables them to instantly communicate, over an electronic hedge, with online peers who may never meet face-to-face, but can advice, sympathize and relate. Finally, several studies suggest that farmers tend to prefer kinesthetic ("learn by doing") or audio/visual learning to other learning styles. As a result, IT now can allow farmers to view or record videos, listen to recordings and watch live web-streaming of conferences, with the subsequent benefit of enabling them to develop their knowledge and learning without having to leave their farms (Burbi, S. Hartless Rose, K. 2016, p. 2).

The use of social media sites help to enable collaboration, information sharing and partnerships for innovation among literate farmers, stakeholders, extensionists and other actors. Enabling farmers and others to "gain a voice", offering localized and customized information, helping to share and manage the information are the main advantage in using social media in agricultural extension services. Also social media creates meaningful relationships with customers and improves market intelligence and get ahead with competitors (Jijina C.K., Raju G., 2016, p.23).

Major agricultural companies are currently using various forms of social media such as YouTube, Twitter, and Facebook. Social media and agricultural companies have the potential to build strong connections between consumers, workers, and the general public with technical, relevant, and interesting information (Carter, J, 2013).

Technical and educational illiteracy, unavailability of high speed Internet connection and recording equipment, unauthentic information, data charges and accessing device are the main limitations in the use of social media (Jijina C.K1, Raju G., 2016, p.24). 


\section{Research method}

The aim of the research was to determine the correlation between the farmer innovativeness and its adoption of the Internet and social media. In addition, the purpose was to determine whether there are differences in the demographic characteristics of farmers, which can be classified as an innovator, early adopter, early majority, late majority and laggards, according to the tendency to use innovative products and technologies.

The hypotheses from which we proceed are:

H1: There is a positive correlation between the farmer innovativeness and the degree of use the Internet and social media.

$\mathrm{H} 2$ : There is a statistically significant difference in farmer innovativeness depending on its gender, age and education.

The research of farmers was carried out between February and June 2016. in the territory of the Autonomous Province of Vojvodina. The sample consisted of 125 randomly selected respondents. The survey method was applied, while the survey instrument was a questionnaire. The questionnaire is created for the purpose of this research and it is not standardized.

The data obtained in this study were processed using "Statistica" software. The following statistical methods were used: Descriptive statistics, Correlation analysis using Pearson's correlation coefficients and Chi-square. The results of the survey are expressed numerically and shown in the table.

\section{Results and Discussion}

The results obtained in the study were summarized and shown in the Table 1.

Table 1. Farmer innovativeness

\begin{tabular}{|c|c|c|c|c|}
\hline No. & Question & The answer & Count & Percent \\
\hline \multirow{5}{*}{1.} & \multirow{5}{*}{$\begin{array}{l}\text { Assess the extent to which you are } \\
\text { open to new ideas. }\end{array}$} & Completely & 28 & $22.40 \%$ \\
\hline & & To greater extent & 30 & $24.00 \%$ \\
\hline & & \begin{tabular}{|l|} 
Average \\
\end{tabular} & 24 & $19.20 \%$ \\
\hline & & To lesser extent & 15 & $12.00 \%$ \\
\hline & & Not at all & 28 & $22.40 \%$ \\
\hline \multirow{5}{*}{2.} & \multirow{5}{*}{$\begin{array}{l}\text { Assess the degree to which you have } \\
\text { the tendency to try new products and } \\
\text { technologies. }\end{array}$} & Completely & 26 & $20.80 \%$ \\
\hline & & \begin{tabular}{|l|} 
To greater extent \\
\end{tabular} & 26 & $20.80 \%$ \\
\hline & & \begin{tabular}{|l|} 
Average \\
\end{tabular} & 29 & $23.20 \%$ \\
\hline & & To lesser extent & 16 & $12.80 \%$ \\
\hline & & Not at all & 28 & $22.40 \%$ \\
\hline
\end{tabular}




\begin{tabular}{|l|l|l|l|l|}
\hline \multirow{4}{*}{3.} & \multirow{4}{*}{$\begin{array}{l}\text { Assess the extent to which you have } \\
\text { resistance to change in your habits and } \\
\text { routines. }\end{array}$} & Completely & 20 & $16.00 \%$ \\
\cline { 3 - 5 } & & To greater extent & 34 & $27.20 \%$ \\
\cline { 3 - 5 } & Average & 22 & $17.60 \%$ \\
\cline { 3 - 5 } & To lesser extent & 28 & $22.40 \%$ \\
\cline { 3 - 5 } & Not at all & 21 & $16.80 \%$ \\
\hline \multirow{4}{*}{$\begin{array}{l}\text { Categorization of farmers based on the } \\
\text { previous three questions. }\end{array}$} & Innovators & 24 & $19.20 \%$ \\
\cline { 3 - 5 } & & Early adopters & 29 & $23.20 \%$ \\
\cline { 3 - 5 } & Early majority & 26 & $20.80 \%$ \\
\cline { 3 - 5 } & Late majority & 20 & $16.00 \%$ \\
\cline { 3 - 5 } & Laggards & 26 & $20.80 \%$ \\
\hline
\end{tabular}

Source: Created by authors based on the survey

Based on the data presented in table no. 1 we can notice that the answers to questions that measure the farmer innovativeness by assessing its openness, enthusiasm for testing new products and resistance to changing habits are similar. This indicates that farmers who are open to new ideas have the most common tendency to try new products and lesser resistance to change personal habits and routines. However, although small, certain differences in answers are existed. The highest level of farmer innovativeness is given answering to the question of the farmer openness for new ideas, while the smallest degree of innovation comes answering to the question about resistance to changes in habits. This point out the fact that people will give better ratings when someone ask they about their openness for new ideas than when someone asks how willing they are to change their habits.

Based on the farmers' score, three arithmetic means were calculated for the three questions, and farmers were classified into five categories according to the degree of innovation. It is evident that $19.20 \%$ of farmers are classified as innovators, while $23.20 \%$ are early adopters. These two groups of farmers are particularly important because they represent the bearers of development and innovation in agriculture. Early majority is made up of $20.80 \%$ of farmers. They are also important because they are also ready to adopt innovations when they see other farmers as users of innovations (innovators and early adopters). Late majority, 16\% of them, are farmers who need a lot of time to adopt innovation, while $20.80 \%$ of farmers are loyal to tradition and established routines and thus it is difficult to persuade them to use innovative products, services and technologies. It is positive that this percentage, although significant, is not too high in this sample.

Table 2. Level of use of the Internet and social media

\begin{tabular}{|l|l|l|l|l|}
\hline No. & Question & The answer & Count & Percent \\
\hline \multirow{4}{*}{$\begin{array}{l}\text { Do you use the Internet, } \\
\text { how often? }\end{array}$} & Every day & 67 & $53.60 \%$ \\
\cline { 3 - 5 } & Few days a week & 10 & $8.00 \%$ \\
\cline { 3 - 5 } & Once a week & 12 & $9.60 \%$ \\
\cline { 3 - 5 } & Once a month & 7 & $5.60 \%$ \\
\cline { 3 - 5 } & I do not use the Internet & 29 & $23.20 \%$ \\
\hline
\end{tabular}




\begin{tabular}{|c|c|c|c|c|}
\hline \multirow{5}{*}{2.} & \multirow{5}{*}{$\begin{array}{l}\text { Do you use the Facebook, } \\
\text { how often? }\end{array}$} & Every day & 42 & $33.60 \%$ \\
\hline & & Few days a week & 14 & $11.20 \%$ \\
\hline & & Once a week & 4 & $3.20 \%$ \\
\hline & & Once a month & 3 & $2.40 \%$ \\
\hline & & Never & 62 & $49.60 \%$ \\
\hline \multirow{5}{*}{3.} & \multirow{5}{*}{$\begin{array}{l}\text { Do you use Instagram, how } \\
\text { often? }\end{array}$} & Every day & 19 & $15.20 \%$ \\
\hline & & Few days a week & 6 & $4.80 \%$ \\
\hline & & Once a week & 3 & $2.40 \%$ \\
\hline & & Once a month & 2 & $1.60 \%$ \\
\hline & & Never & 95 & $76.00 \%$ \\
\hline \multirow{5}{*}{4.} & \multirow{5}{*}{$\begin{array}{l}\text { Do you use Twitter, how } \\
\text { often? }\end{array}$} & Every day & 5 & $4.00 \%$ \\
\hline & & Few days a week & 6 & $4.80 \%$ \\
\hline & & Once a week & 1 & $0.80 \%$ \\
\hline & & Once a month & 0 & $0.00 \%$ \\
\hline & & Never & 113 & $90.40 \%$ \\
\hline \multirow{5}{*}{5.} & \multirow{5}{*}{$\begin{array}{l}\text { Do you watch videos on } \\
\text { YouTube, how often? }\end{array}$} & Every day & 15 & $12.00 \%$ \\
\hline & & Few days a week & 37 & $29.60 \%$ \\
\hline & & Once a week & 17 & $13.60 \%$ \\
\hline & & Once a month & 16 & $12.80 \%$ \\
\hline & & Never & 40 & $32.00 \%$ \\
\hline
\end{tabular}

Source: Created by authors based on the survey

Based on the data presented in Table 2, we notice that $53.60 \%$ of the farmers use the Internet every day, and $8 \%$ of them use it several times a week. This is significantly lower than in the US and in line with the level of Internet usage in Europe. These farmers are the ones who can be responsible for the introduction of new ICT solutions in agriculture. However, the fact that $23.20 \%$ does not use the Internet shows that there is still a significant percentage of farmers who have not accepted the Internet and do not take advantage of the use of the Internet in their business, which may be related to their personal concept and resistance to changes and innovative products. When we consider the degree of use of Facebook, we notice that $33.60 \%$ of farmers use the Internet every day, while $11.20 \%$ of them use Facebook several times a week, which are also quite good indicators. $49.60 \%$ of farmers still do not use Facebook. Instagram is a network used by a relatively small number of farmers (15.20\% every day, and $4.80 \%$ few times a week). Thus, the total percentage of farmers that use this network intensely is $20 \%$, those who use it once a week or once a month is almost negligible, while $76 \%$ have never used this network. Considering that the Instagram is network that appeared later in relation to Facebook in Serbia and began to be more intensively used in the last two years, it is expected that it is still not accepted among the wide population and that the number of Instagram users is lower compared to Facebook users. Twitter is definitely a network that has no relevance for farmers in Serbia unlike the US, since $90.40 \%$ of respondents have never used this network. YouTube is a social medium that is watched by only $12 \%$ of farmers every day, but $29,6 \%$ of farmers watch it few times a week, which represents $41.60 \%$ of the respondents, making YouTube a medium with a significant degree of use. In addition, it is interesting to note that the smallest 
percentage of farmers never used YouTube (32\%). This data also confirms significant degree of using YouTube by farmers.

Table 3. Pearson's correlation coefficients

\begin{tabular}{|l|l|l|l|l|l|}
\hline & $\begin{array}{l}\text { Using } \\
\text { Internet }\end{array}$ & $\begin{array}{l}\text { Using } \\
\text { Facebook }\end{array}$ & $\begin{array}{l}\text { Using } \\
\text { Instagram }\end{array}$ & $\begin{array}{l}\text { Using } \\
\text { Twitter }\end{array}$ & $\begin{array}{l}\text { Using } \\
\text { YouTube }\end{array}$ \\
\hline $\begin{array}{l}\text { The degree of openness for } \\
\text { new ideas }\end{array}$ & $0.74^{*}$ & $0.54^{*}$ & $0.42^{*}$ & $0.27^{*}$ & $0.54^{*}$ \\
\hline $\begin{array}{l}\text { The degree of inclination } \\
\text { to try new technologies, } \\
\text { products and services }\end{array}$ & $0.70^{*}$ & $0.52^{*}$ & $0.41^{*}$ & $0.26^{*}$ & $0.52^{*}$ \\
\hline $\begin{array}{l}\text { Degree of resistance to } \\
\text { changes in habits }\end{array}$ & $-0.66^{*}$ & $-0.63^{*}$ & $-0.49 *$ & $-0.41^{*}$ & $-0.54^{*}$ \\
\hline
\end{tabular}

* Correlations are significant for $p<0.001$

Source: Created by authors based on the survey

In order to determine whether there is a correlation between answers used to measure by farmers innovativeness and the degree of farmers' use the Internet and social media, Correlation analysis using Pearson's correlation coefficients is applied. Based on the results obtained in Table no. 3 it can be concluded that all three questions that used to measure the innovativeness of farmers are significantly related to the use of the Internet, Facebook, Instagram, Twitter and YouTube at $p<0.001$. In the first two responses concerning the degree of openness for new ideas and the degree of tendency to try new technologies, products and services, the correlation coefficient is a positive. This means that, if farmers are more open to new ideas and are more willing to try new technologies, products and services, the level of using the Internet and social media will be higher. For the third response that relates to the degree of resistance to changes, the correlation coefficient is a negative. Thus, if farmers have a greater resistance to change, their use of the Internet and social media will be lesser. The highest values of correlation coefficients were established between all three indicators of farmers' innovativeness and degree of Internet use, while the lower values of correlation coefficients were obtained between farmer innovativeness and the use of Twitter. The obtained values are analogous to the fact that the Internet is most intensively used by farmers and the Twitter at least.

Table 4. Farmer demographic characteristics and the degree of their innovativeness

\begin{tabular}{|c|c|c|c|c|c|c|c|c|}
\hline $\begin{array}{l}\text { Demograr } \\
\text { factors }\end{array}$ & Men & Women & -30 & $31-50$ & $51+$ & $\begin{array}{l}\text { Primary } \\
\text { school }\end{array}$ & $\begin{array}{l}\text { Secondary } \\
\text { school }\end{array}$ & $\begin{array}{l}\text { BSc, MSci, } \\
\text { Ph. D }\end{array}$ \\
\hline $\begin{array}{l}\text { Categories } \\
\text { of } \\
\text { innovation }\end{array}$ & \multicolumn{2}{|c|}{$\begin{array}{l}\text { Chi-Square }=11.66 \\
d f=4, c v=9.49 \\
p=0.05\end{array}$} & \multicolumn{3}{|c|}{$\begin{array}{l}\text { Chi-Square }=43.83 \\
\mathrm{df}=8 \mathrm{cv}=15.51, \mathrm{p}=0.05\end{array}$} & \multicolumn{3}{|c|}{$\begin{array}{l}\text { Chi-Square }=31.72 \mathrm{df}=8, \mathrm{cv}=15.51, \\
\mathrm{p}=0.05\end{array}$} \\
\hline
\end{tabular}




\begin{tabular}{|l|l|l|l|l|l|l|l|l|l|}
\hline \multicolumn{2}{|l}{$\begin{array}{l}\text { Demographic } \\
\text { factors }\end{array}$} & Men & Women & $\mathbf{- 3 0}$ & $\mathbf{3 1 - 5 0}$ & $\mathbf{5 1}+$ & $\begin{array}{l}\text { Primary } \\
\text { school }\end{array}$ & $\begin{array}{l}\text { Secondary } \\
\text { school }\end{array}$ & $\begin{array}{l}\text { BSc, MSci, } \\
\text { Ph. D }\end{array}$ \\
\hline \multirow{2}{*}{ Innovators } & No. & 14 & 10 & 14 & 5 & 5 & 2 & 11 & 11 \\
\cline { 2 - 10 } & $\%$ & 58.33 & 41.67 & 58.34 & 20.83 & 20.83 & 8.34 & 45.83 & 45.83 \\
\hline \multirow{2}{*}{$\begin{array}{l}\text { Early } \\
\text { adopters }\end{array}$} & No. & 24 & 5 & 11 & 13 & 5 & 3 & 17 & 9 \\
\cline { 2 - 10 } & $\%$ & 82.76 & 17.24 & 37.93 & 44.83 & 17.24 & 10.35 & 58.62 & 31.03 \\
\hline \multirow{2}{*}{$\begin{array}{l}\text { Early } \\
\text { majority }\end{array}$} & $\%$ & 92.31 & 7.69 & 7.69 & 42.31 & 50 & 19.23 & 80.77 & 0 \\
\cline { 2 - 10 } & No. & 24 & 2 & 2 & 11 & 13 & 5 & 21 & 0 \\
\hline \multirow{2}{*}{$\begin{array}{l}\text { Laggards } \\
\text { majority }\end{array}$} & $\%$ & 70 & 30 & 25 & 35 & 40 & 30 & 45 & 25 \\
\hline & No. & 14 & 6 & 5 & 7 & 8 & 6 & 9 & 5 \\
\hline
\end{tabular}

Source: Created by authors based on the survey

Based on the data presented in Table 4, it can be noticed that differences in the level of farmer innovativeness depending on gender. The difference between genders was established using Chi-square test for independent samples, where the dependent variable was answer to the question about the degree of farmer innovativeness, while the grouping variables were the gender of respondents. Since the Chi-square was greater (11.66) than the critical value of 9.49 for $\mathrm{df}=2$ and $\mathrm{p}=0.05$, we can conclude that there is a statistical significance of the dependent variable in relation to the gender. This means that gender as a demographic factor has a significant impact on the farmer innovativeness. Analyzing the descriptive statistics about participation of men and women in groups of farmers classified according to the innovativeness, we can notice that men dominate in all groups because their share in the overall sample of respondents is much higher than women share. Despite this fact, percentage of women is at most present in the group of innovators, while men are dominant in early majority group. Thus we can conclude that women among farmers are those that are more willing to adopt innovations, which is important to take into account in the process of creating marketing strategies related to the introducing ICT innovations in agriculture. 
In order to determine whether there are statistically significant relation between farmers' age and its innovativeness, we used the Chi-square test and confirmed that farmers' innovativeness is related to its age, given that $\chi 2=43.83$ at $\mathrm{df}=8, \mathrm{cv}=15.51$ and $\mathrm{p}=$ 0.05 . Based on the results of descriptive statistics, we can conclude that younger farmers, up to 30 years, are the most represented in the category of innovators; farmers between 30 and 50 years are the most represented in the early adopters and early majority category, while people over the age of 50 at most belongs to the laggards group.

The connection between the innovativeness of the farmers and their education was also checked by the Chi-square test, and since $\chi 2=31.72$ at $\mathrm{df}=8, \mathrm{cv}=15.51$ and $\mathrm{p}=0.05$, it can be concluded that there are statistically significant relation between the farmer innovativeness and its education. Based on descriptive statistics, we note that those with higher education were primarily in the category of innovators and early adopters, the farmers with secondary education are at most were in the early majority category, while those with primary education are predominantly were in the laggards category. This is important to keep in mind when creating marketing strategies because farmers those are more educated will more likely fall into the group of innovators.

The obtained results are in line with numerous studies that showed a positive correlation between the demographic characteristics of consumers and innovation.

\section{Conclusion}

We confirmed the hypothesis that there is a correlation between farmer innovativeness and its acceptance the Internet and social media. If the farmers are more open to new ideas and trying new products, services and technologies and have less resistance to changes in habits, their use of the Internet and social media is greater. Considering that in this sample $53.60 \%$ of the respondents stated that they use the Internet every day, this means that the Internet is used by farmers who belong to the group of innovators, early adopters and a part of the early majority. Therefore, the increase in Internet usage is expected in the future because it is expected that other farmers who belong to the group of early majority, who have not yet started using the Internet, will start using it. Likewise, members of the late majority group are expected to start using the Internet, while for the laggards group it is uncertain how much they will be interested in using the Internet and their percentage in this sample is $20.80 \%$. Farmers are the most interested in Facebook and YouTube and their further intensive use is also expected. Instagram and Twitter are networks that are not yet widely accepted among farmers and are used by farmers who have the highest degree of innovativeness and the desire to try new things.

In addition, we have also analyzed how many demographic factors affect the farmer innovativeness. Based on the obtained results, we can accept the starting hypothesis that there is a statistically significant relation between farmers' innovativeness and their gender, age and education. The survey showed that female farmers, persons up to 30 years and those with higher education have the highest degree of innovativeness and they can be classified as innovators. Man between 30 and 50 years of secondary 
education at most belong to the early adopters and early majority group. Late majority is mostly consisted of men over 50, but also those between 30 and 50 years old with secondary education. Men over 50 years old with primary school belong to the laggards group. Thus, the Internet and social media are currently mostly used by women and men of higher education and secondary education up to 50 years old and it is expected that their use will extend to men of secondary education who belong to the late majority.

According to the obtained results, a number of recommendations for marketing strategy creators can be drawn. When introducing new ICT solutions in agriculture, it is necessary to focus on farmers with the highest degree of innovativeness. The most innovative farmers are women, younger than 30 years old, with higher education, so they should be the basic target market. But having in mind that there is the low participation of women in agriculture, companies should also focus on men between 30 and 50 years old, with secondary education. These demographic characteristics are very important to know when company makes marketing mix: product, price, distribution and promotion. A personal sale is most effective when company introduces new ICT products, but it is also very important to intensively apply the methods of Internet marketing. It is necessary to put special emphasis on SEO websites and intensive promotion through Facebook and YouTube.

The limitation of this study is in a relatively small sample of farmers and it is recommended that in the next research an examined sample of farmers be increased in order to obtain even more precise data.

\section{Literature}

1. Burbi, S., Hartless R., K. (2016) The role of Internet and social media in the diffusion of knowledge and innovation among farmers, https://www.researchgate. net/publication/305391623 25.4.2017.

2. Carter, J, (2013). Who's Trending in Agriculture? A Look at Social Media. Natural Sciences Education, 42(1), 33-35.

3. Citrin, A. V., Sprott, D. E., Silverman, S. N., Stem Jr., D. E. (2000). Adoption of Internet shopping: The role of consumer innovativeness. Industrial Management and Data Systems, 100 (7), 294-300.

4. Ćirić, M., Kuzman, B. (2017). Are Farmers Ready for Changes that Internet and Social Media Bring? International Conference -Innovation, ICT and education for the next generation, May 26-27, Faculty of Economics and Engineering Management in Novi Sad, 81-97.

5. Farmers Weekly (2016). Farmers Weekly Magazine. http://www.fwi.co.uk 23.4.2017.

6. Guerrini, F. (2015). The future of agriculture? Smart farming. Forbes, https://www. forbes.com/sites/federicoguerrini/2015/02/18/the-future-of-agriculture-smartfarming/\#682d43883c42 23.4.2017. 
7. Hilgard, E., Atkinson, R. (1975). Introduction to psychology. 6th ed. New York: Harcourt Brace Jovanovich.

8. Jijina C.K, Raju G., (2016). Social media and farmers. International Journal of Research in Engineering and Technology, 5(19), 20-25.

9. Kaushik, A.K., Rahman, Z., (2014). Perspectives and Dimensions of Consumer Innovativeness: A Literature Review and Future Agenda. Journal of International Consumer Marketing, 26(3), 239-263.

10. Kotler, F. (1988). Upravljanje marketingom. Informator, Zagreb.

11. Ljubojević, Č. Ćirić, M. (2017). Marketing usluga. Fakultet za ekonomiju i inženjerski menadžment, Novi Sad.

12. Novaković, Rajačić, B. (2005). Ponašanje potrošača. Evropski univerzitet, Beograd.

13. Novalić, F., Selimović, F. i Biševac, F. (2011). Uticaj Interneta na razvoj poljoprivrede. Naučna konferencija -AGROBIZNIS2011, 10. oktobar, Univerzitet u Novom Pazaru, 470-479.

14. Pauwels, K., Silva-Risso, J., Srinivasan, S., Hanssens, D. M. (2004). New products, sales promotions, and firm value: The case of the automobile industry. Journal of Marketing, 68, 142-156.

15. Roehrich, G. (2004). Consumer Innovativeness: Concepts and Measurements. Journal of Business Research, 57 (6), 671-77.

16. Rogers, E. M. (1962). Diffusion of Innovations. Free Press, New York.

17. Srinivasan, S., K. Pauwels, J. Silva-Risso, and D. M. Hanssens. (2009). Product innovations, advertising, and stock returns. Journal of Marketing, 73, 24-43.

18. Tellis, G. J., Yin, E., Bell, S., (2009). Global Consumer Innovativeness: CrossCountry Differences and Demographic Commonalities. Journal of International Marketing, 17(2), 1-22.

19. Xin, J. N., Zazueta, F. (2016). Technology trends in ICT - towards data-driven, farmer-centered and knowledge based hybrid cloud architectures for smart farming. Agricultural Engineering International, CIGR Journal, 18(4), 275-279. 


\title{
INOVATIVNOST POLJOPRIVREDNIH PROIZVOĐAČA I NJEN \\ UTICAJ NA PRIHVATANJE INTERNETA I DRUŠTVENIH MEDIJA
}

\author{
Maja Ćirić6, Marko Carič'7, Boris Kuzman ${ }^{8}$, Ana Zekavica ${ }^{9}$
}

\begin{abstract}
Sažetak
Poslednjih godina ogromni napori se ulažu u pronalaženje načina da se implementiraju ICT inovacije u sektor poljoprivrede ne bi li se povećala njegovu konkurentnost. Pitanje koje se može postaviti jeste od čega zavisi uspeh implementacije ICT inovacija među poljoprivrednim proizvođačima. Brojni naučni radovi pisani su sa svrhom da identifikuju faktore koji utiču na to da li će određena inovacija biti prihvaćena od strane korisnika. Cilj ovog rada jeste da se utvrdi da li je inovativnost poljoprivrednih proizvođača faktor koji utiče na prihvatanje i stepen korišćenje interneta i društvenih medija od strane poljoprivrednih proizvođača. Osim toga nastoji se utvrditi da li postoji statistički značajna povezanost demografskih faktora poljoprivrednih proizvođača $i$ njihove inovativnosti. Za potrebe istraživanja primenjena je metoda ankete. Od statističkih metoda korišćena je deskriptivna statistika, korelacije i Hi kvadrat test. Dobijeni rezultati potvrdili su početne hipoteze i na osnovu toga su date preporuke za kreiranje marketing strategije prilikom uvođenja novih ICT rešenja u oblasti poljoprivrede.
\end{abstract}

Ključne reči: inovativnost poljoprivrednih proizvođača, internet, društveni mediji, istraživanje tržišta, demografske karakteristike, precizna poljoprivreda

6 Maja Ćirić, Vanredni profesor, Fakultet za ekonomiju i inženjerski menadžment u Novom Sadu, 021/400-484 majaciric79@yahoo.com

7 Marko Carić, Redovni profesor, Pravni fakultet za privredu i pravosuđe, Novi Sad, marko@ pravni-fakultet.info

8 Boris Kuzman, Vanredni profesor, Institut za ekonomiku poljoprivrede, Beograd, kuzmanboris@yahoo.com

9 Ana Zekavica, Asistent, Beogradska poslovna škola, ana.zekavica@gmail.com 